\title{
STUDI ANALISIS ISI: REPRESENTASI KRITIK POLITIK DAN IDEOLOGI KOMUNIS PADA LUKISAN KARYA HENDRA GUNAWAN
}

\author{
IVAN KURNIAWAN ${ }^{1}$, MUHAMMAD LUTFI ARIS² \\ Universitas Komputer Indonesia ${ }^{1,2}$ \\ Ivan.kurniawan@email.unikom.ac.id
}

\begin{abstract}
This study seeks to explore the political interests and ideology of communism which are considered to be represented in the paintings of Hendra Gunawan by the Orde Baru regime. Using the content analysis method, this study will review the intent that Hendra Gunawan was trying to convey in 10 paintings themed on people's lives from 1950 to 1968, a phase where political party intervention in art is suspected. The results showed that there was a match between the political interests of the communist group and the interpretation of the painting in the form of messages expressed by Hendra in his paintings. By looking at the compatibility between the message conveyed by Hendra in his painting, and the indicators designed based on the Prinsip Kesenian 1959, most of which contain the political interests of the communist group in the cultural realm. So it can be concluded that Hendra Gunawan's painting is a painting that is quite ideal for the interests of the communist group, by fulfilling 4 of 5 aspects, namely ideological aspects, class struggle, cultural values, and practical aspects. However, the nonfulfillment of 1 aspect in the form of describing the ideal conditions of the revolution resulted in the possibility of Hendra's idealism being maintained, a possibility that is also a weakness of this research, in addition to the focus of research which only raises 1 character. Apart from that, it is very important to reveal the facts about Hendra Gunawan, because at that time Hendra with his work was recognized as one of the widely known masters of painting. It is hoped that, even though his paintings contain the ideology of communism, this does not necessarily become the reason for the disappearance of Hendra's figure from history books. Because by eliminating the name Hendra Gunawan, it means you have removed an important part of the Indonesian art heritage.
\end{abstract}

Key Words : representation, politics, communism, paintings, hendra gunawan

\begin{abstract}
ABSTRAK
Penelitian ini berupaya menggali kepentingan politik dan ideologi komunisme yang dianggap terepresentasi dalam lukisan Hendra Gunawan oleh rezim Orde Baru. Dengan menggunakan metode analisis isi, penelitian ini akan melihat kembali maksud yang berusaha disampaikan Hendra Gunawan dalam 10 lukisan bertema kehidupan rakyat yang berasal dari rentang tahun 1950-1968, suatu fase dimana intervensi partai politik dalam ranah kesenian dicurigai banyak terjadi. Hasil penelitian menunjukkan adanya kesesuaian antara kepentingan politik kelompok komunis dengan hasil interpretasi lukisan berupa pesan yang diungkapkan Hendra dalam lukisannya. Dengan melihat kesesuaian antara pesan yang disampaikan Hendra dalam lukisannya, dengan indikator yang dirancang berdasarkan Prinsip Kesenian 1959 yang banyak memuat kepentingan politik kelompok komunis diranah kebudayaan. Sehingga dapat disimpulkan bahwa lukisan Hendra Gunawan merupakan lukisan yang cukup ideal bagi kepentingan kelompok komunis, dengan memenuhi 4 dari 5 aspek, yaitu aspek ideologis, perjuangan kelas, nilai budaya, dan aspek praktis. Namun tidak terpenuhinya 1 aspek berupa penggambaran kondisi ideal revolusi menghasilkan kemungkinan bahwa idealisme Hendra masih terjaga, satu kemungkinan yang sekaligus
\end{abstract}


menjadi kelemahan dari penelitian ini, selain dari fokus penelitian yang hanya mengangkat 1 tokoh. Terlepas dari hal tersebut upaya pengungkapan fakta tentang Hendra Gunawan sangat penting untuk dilakukan, sebab pada masanya Hendra dengan karyanya diakui sebagai salah satu maestro lukis yang dikenal secara luas. Diharapkan, meski ideologi komunisme terdapat dalam karya lukisannya, namun hal itu tidak serta merta dapat dijadikan alasan hilangnya sosok Hendra dari buku-buku sejarah. Karena dengan menghapus nama Hendra Gunawan, berarti telah menghilangkan salah satu bagian penting dari dunia kesenian Indonesia.

Kata Kunci: Komunisme, Ideologi, Lukisan, Hendra Gunawan

\section{PENDAHULUAN}

Panasnya situasi politik di Indonesia sepanjang tahun 1950-1965 ikut dirasakan hingga ranah kebudayaan, banyak pelukis dan lukisan yang dianggap terafiliasi salah satu faham atau partai politik hingga karyanya dianggap merepresentasikan kepentingan kelompok tersebut. Puncak dari situasi tersebut, pasca G 30 S 1965 mendorong munculnya tindak kekerasan budaya oleh rezim Orde Baru yang menimpa seniman beraliran realisme sosialis yang dianggap terafiliasi Partai Komunis Indonesia dan ideologi komunisme, termasuk seniman Hendra Gunawan. Karya-karya Hendra yang diproduksi dalam rentang tahun 1960-1968, dilarang beredar sejak tahun 1965, yang membuat karyanya yang cukup dikenal luas pada masanya seolah menghilang, dan tidak lagi dikenal secara luas. Padahal menurut Sidharta dalam Suryajaya [1] penangkapan terhadap sejumlah tokoh dan pemusnahan karya seni, menyebabkan adanya mata rantai yang hilang dari sejarah seni rupa di Indonesia. Menurutnya, mata rantai yang hilang tersebut merekam gambaran perkembangan seni rupa pada masanya yang tidak akan didapat dari karya yang terlahir dari periode lain. Sosok Hendra Gunawan dan lukisannya juga menjadi salah satu objek sentral yang penting untuk dikaji lebih jauh, sebab pada masanya Hendra dikenal sebagai seniman besar dan memiliki karya yang sangat khas, represi yang dilakukan Orde Baru terhadapnya sangat terasa dampaknya hingga kini, dimana sosoknya seperti hilang dari pembahasan buku-buku sejarah kesenian, dan karyanya tidak lagi dikenali secara luas.

Pembahasan tentang tindakan represi terhadap seniman dan karyanya pasca G/30 S PKI 1965 pernah dibahas dalam beberapa penelitian sebelumnya, seperti disertasi doktoral Herlambang [2], yang membahas tentang tujuan pelarangan karya realisme sosialis yang berkaitan dengan upaya untuk menyebarkan ideologi liberalisme. Kemudian buku karya Supartono [3] yang menyoroti pelarangan karya sebagai konflik kebudayaan yang dimanfaatkan 2 ideologi besar yang ada saat itu. Sementara kedua penelitian diatas berfokus pada situasi politik yang berkembang, penelitian ini akan berfokus pada artefak lukisan, untuk melihat kecenderungan seperti apa yang ditunjukan dalam lukisan.

Sebelumnya penelitian yang berangkat melalui penelusuran karya lukisan sebenarnya pernah dilakukan oleh Djajadi [4] namun dalam penelitiannya Djajadi berfokus pada pembandingan karya realisme sosialis di Indonesia dengan karya realisme sosialis di Uni Sovyet dan Tiongkok, untuk menunjukan bahwa realisme sosialis yang berkembang di Indonesia tidak digunakan sebagai propaganda ideologi komunisme seperti yang terjadi di kedua negara sebelumnya. Sementara itu, penelitian ini akan mengesampingkan terlebih dahulu tren yang berkembang diluar, dan berfokus pada pesan yang terkandung dalam lukisan, untuk melihat permasalahan dari posisi yang lebih berimbang.

Pada penelitian sebelumnya Herlambang [2] dan Supartono [3] hanya berfokus pada latar belakang politik dan mengesampingkan objek karya sehingga penelitian hanya didasarkan pada penilaian terhadap situasi yang berkembang sementara Djajadi [4] hanya meneliti karya- karya yang dianggap kontroversial, sehingga penilaian terhadap seluruh karya realisme sosialis di Indonesia hanya didasarkan pada karya yang memang cenderung menunjukan orientasi politik dan kepentingan salah satu ideologi. Yang terpenting ketiganya juga tidak secara khusus mengkaji karya Hendra Gunawan seperti dalam penelitian ini, sehingga penelitian ini sangat penting dilakukan untuk memastikan kecenderungan politik seperti apa yang sebenarnya terdapat dalam Iukisan Hendra Gunawan yang tidak didapatkan pada ketiga penelitian sebelumnya. 


\section{METODE}

Dalam penelitian ini digunakan metode kualitatif dengan analisis isi. Menurut Krippendorff dalam Kurniawan [5] analisis isi adalah teknik penelitian untuk menciptakan inferensi yang dapat direplikasi dan benar datanya dengan menggunakan dan memperhatikan konteksnya.

Analisis isi sendiri merupakan salah satu metode yang pada awalnya muncul sebagai bagian dari penelitian komunikasi dengan sumber berupa teks, namun dalam perkembangannya, metode ini juga banyak digunakan sebagai metode analisis terhadap artefak visual, seperti dalam Kurniawan [5]_yang menggunakan analisis isi untuk menghitung kecenderungan fetishisme dan sensualitas fotografer pemula dalam sebuah komunitas jejaring sosial. Juga digunakan oleh Kurniawan, dan Rochmawati [6] yang menghitung representasi yang muncul dari serangkaian iklan dalam bentuk video. Metode yang sama juga digunakan oleh Firmansyah [7] kala mengungkap representasi nasionalisme dalam film 300 dan Mudjiyanto [8] saat mengungkap representasi umat Islam dalam Tajuk Rencana surat kabar ibukota mengenai kasus Makam Mbah Priok.

Analisis isi sendiri dapat digunakan untuk meneliti artefak visual sebab seperti disebutkan Bhartes dalam Kurniawan [5] setiap objek visual dapat dibaca layaknya teks, sehingga metodemetode yang biasa digunakan dalam menganalisa artefak berbentuk teks, dapat digunakan dalam penelitian dengan objek data visual seperti dalam penelitian ini. Dalam prosesnya, pada penelitian ini, analysis isi akan dilakukan pada objek berupa lukisan, dengan penghitungan hasil interpretasi terhadap lukisan menggunakan sebuah rangkaian matrix coding untuk mengukur pesan seperti apa yang kemudian terepresentasi oleh lukisan Hendra Gunawan.

\section{Objek Penelitian}

Dalam penelitian ini objek yang diteliti adalah Karya lukisan Hendra Gunawan yang bertema kehidupan rakyat dan diproduksi sepanjang tahun 1960-1968. Alasannya karyakarya ini dianggap sebagai bagian dari kepentingan politik PKI dalam penyebaran faham komunisme. Berdasarkan dua indikator yang ditetapkan, kemudian didapatkan 10 lukisan yang memenuhi kriteria. Kesepuluh lukisan ini nantinya akan diinterpretasi dengan mengacu pada informasi yang didapat dari literatur yang ada dan hasil wawancara. Untuk menyimpulkan pesan apa saja yang coba disampaikan Hendra melalui lukisannya. Berikut salah satu contoh lukisan yang akan diinterpretasi untuk kemudian dihitung kecenderungan pesan yang disampaikannya:

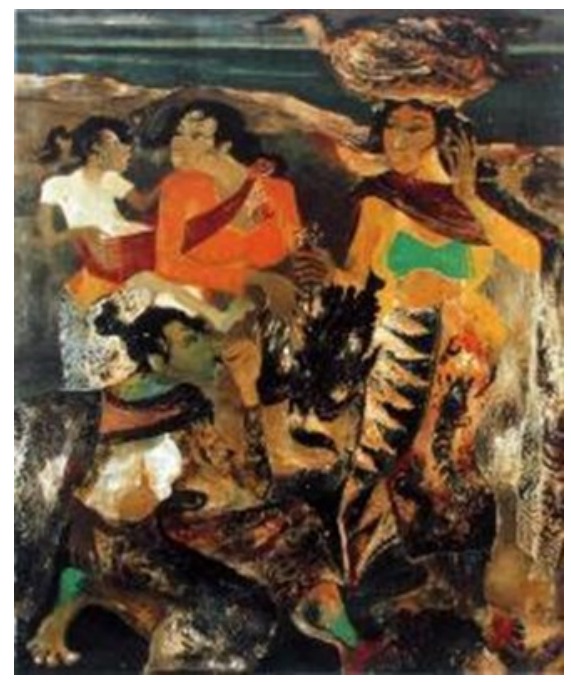

Gambar 1. Lukisan Hendra Gunawan, "Pasar" (1960)

Sumber: www. ivaa-online.org

\section{Prosedur Pengambilan Data}

Langkah pertama dalam peneitian ini adalah menetapkan batasan terhadap lukisan yang akan diteliti, dalam hal ini lukisan dibatasi dengan 2 kriteria yaitu berdasarkan tema lukisan dan tahun produksi. Adapun berdasarkan tema, lukisan yang diteliti adalah lukisan yang menggambarkan kehidupan rakyat dalam prespektif Hendra Gunawan. Batasan kedua berdasarkan rentang waktu yakni tahun 19601968. Rentang tersebut dipilih dengan alasan bahwa pada akhir tahun 1959 Lekra mengeluarkan teks Prinsip Kesenian tahun 1959, teks ini berisi panduan berkesenian bagi seniman realisme sosialis yang menurut pandangan beberapa pihak mengarah pada penetapan atau kanonisasi bentuk-bentuk kesenian yang ideal bagi kepentingan PKI. Sementara itu pembatasan lukisan hingga tahun produksi 1968 dikarenakan terdapat perubahan tema serta gaya gambar yang terjadi pada Hendra Gunawan ketika ditahan oleh rezim Orde Baru.

Berdasarkan kedua batasan tersebut dilakukan penelusuran karya-karya Hendra Gunawan di situs www.ivaa-online.org, situs web yang banyak menyimpan arsip lukisan Hendra Gunawan. Selanjutnya data yang terkumpul akan diamati, dan diinterpretasi serta dilakukan pemisahan data dalam beberapa kategori untuk memudahkan proses penghitungan frekuensi dalam rancangan matrix coding. Pemisahan data seperti ini juga dilakukan dalam penelitian Kurniawan, dan 
Rochmawati [5] serta Djajadi [4]. Rancangan matrix coding yang digunakan sebagai alat ukur sendiri disusun mengacu pada teks Prinsip Kesenian 1959, teks yang berisi panduan pengkaryaan yang dibuat kelompok komunis, perancangan matrix coding mengacu pada sebuah teks seperti ini juga dilakukan oleh Mudjiyanto [11].

\section{Pemisahan Tanda Visual}

Pemisahan tanda visual didasarkan pada hasil Interpretasi yang mengacu pada beberapa sumber literatur, dan wawancara narasumber. Metode ini dilakukan oleh Cahyana dkk [7] dalam meneliti serangkaian karya beberapa seniman di Indonesia.

\section{Metode Analisa}

Pada proses analisa penelitian ini, langkah pertama adalah tahapan interpretasi terhadap objek visual yang telah terkumpul mengacu pada sumber pustaka dan hasil wawancara narasumber. Pengumpulan data dan pemisahan tanda serupa dilakukan dalam penelitian Cahyana dkk [7], dan Djajadi [2].

Tabel 1. Tahapan Analisa Lukisan

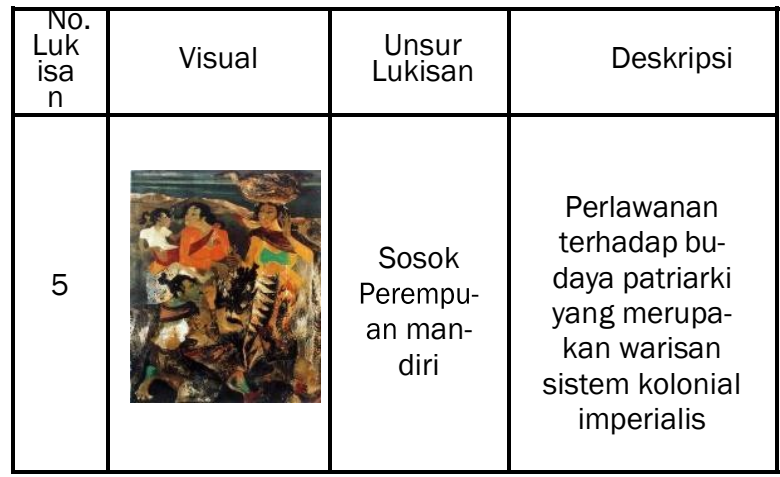

Interpretasi lukisan sperti dalam tabel dilakukan kepada seluruh lukisan yang telah terkumpul untuk elanjutnya dilakukan penghitungan hasil interpretasi menggunakan indikator yang dirancang kedalam sebuah sistem matrix coding. Sistem matrix coding dalam penelitian ini sendiri disusun berdasarkan pada interpretasi terhadap teks pembanding, yaitu teks Prinsip Kesenian 1959 dengan alasan bahwa teks ini dianggap sebagai bentuk intervensi PKI lewat Lekra terhadap proses pengkaryaan seniman realisme sosialis. Metode penyusunan matrix coding ini pernah dilakukan dalam penelitian yang dilakukan Kurniawan dan Rochmawati [5]. Berdasarkan metode tersebut didapatkan 5 indikator yang akan menjadi alat ukur penelitian, adapun kelima indikator antara lain: Aspek Ideologi, Kelas Sosial, Nilai Budaya, Kondisi Objek, dan Pengalaman seniman, yang disusun dalam sistem tabel sebagai berikut:

Tabel 2. Rangkaian Matrix coding

\begin{tabular}{|c|c|c|c|c|c|c|c|}
\hline \multirow{2}{*}{ Coding Unit } & \multirow{2}{*}{ Indikator } & \multicolumn{6}{|c|}{ No. Lukisan } \\
\hline & & 1 & 2 & 3 & 4 & 5 & 6 \\
\hline \multirow{3}{*}{$\begin{array}{l}\text { Ajaran } \\
\text { Ideologi }\end{array}$} & $\begin{array}{l}\text { Komunisme- } \\
\text { Sosialisme }\end{array}$ & & & & & & \\
\hline & Kapitalisme & & & & & & \\
\hline & Bukan Keduanya & & & & & & \\
\hline \multirow{2}{*}{$\begin{array}{l}\text { Kelas } \\
\text { Sosial }\end{array}$} & Borjuis & & & & & & \\
\hline & Proletar & & & & & & \\
\hline \multirow{3}{*}{$\begin{array}{l}\text { Nilai } \\
\text { Budaya }\end{array}$} & Konservatif & & & & & & \\
\hline & Progresif & & & & & & \\
\hline & Bukan keduanya & & & & & & \\
\hline \multirow{2}{*}{$\begin{array}{l}\text { Kondisi } \\
\text { Objek }\end{array}$} & $\begin{array}{l}\text { Penciptaan } \\
\text { kondisi ideal }\end{array}$ & & & & & & \\
\hline & Realitas & & & & & & \\
\hline \multirow{2}{*}{$\begin{array}{l}\text { Pengalaman } \\
\text { Seniman }\end{array}$} & $\begin{array}{l}\text { Berdasarkan } \\
\text { pengalaman }\end{array}$ & & & & & & \\
\hline & $\begin{array}{l}\text { Bukan berdasar } \\
\text { pengalaman }\end{array}$ & & & & & & \\
\hline
\end{tabular}

Adapun langkah terakhir yang dilakukan adalah menganalisis hasil penghitungan dengan indikator dalam matrix coding tersebut. Kemudian akan dihitung untuk melihat persentasi dari faham ideologi dan kepentingan politik yang terepresentasikan oleh lukisan Hendra Gunawan. Penelitian yang menggunakan metode serupa pernah dilakukan Mudjiyanto [8]_serta Kurniawan dan Rochmawati [6].

\section{HASIL}

Dilihat dari beberapa konten lukisan, lukisan 'Mencuci' memiliki visual khas berupa deformasi bentuk. Lukisan ini bercerita tentang kegiatan mencuci pakaian yang dilakukan oleh dua orang perempuan berpakaian kebaya dan sarung batik, yang merupakan pakaian yang biasa digunakan kalangan rakyat pada masa itu. Seting lokasi menggambarkan suasana sebuah sungai dengan air yang digambarkan mengalir jernih, kedua tokoh digambarkan berhadapan dan terlibat dalam perbincangan ditengah kegiatan mereka. 


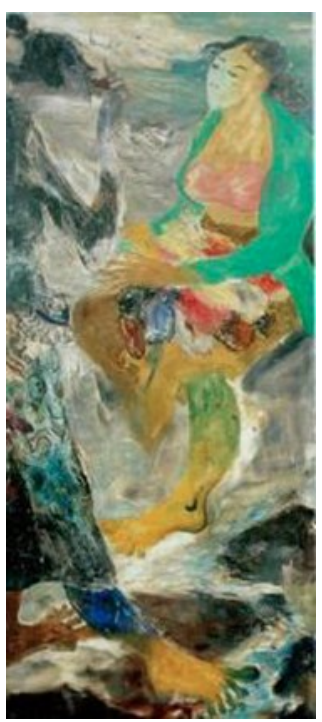

Gambar 2. Lukisan Hendra Gunawan, "Mencuci" (1960)

Sumber:http://archive.ivaa-online.org/pelakuseni/ hendra-gunawan/page:2

Mengenai pesan yang berusaha disampaikan dalam lukisannya, Hendra seringkali menyampaikan pandangannya tentang sosok rakyat kecil lewat gaya melukisnya. Dalam lukisan di atas dapat dilihat jika kaki dari sosok dalam lukisannya digambarkan lebih besar dengan warna yang mencolok. Tentang deformasi bentuk ini Hendra dalam Cahyana [9] menyampaikan jika deformasi bentuk dalam lukisannya bukan sesuatu yang dia lakukan secara sadar, namun lahir karena prosesnya dalam menghayati situasi dan kondisi yang ada. Mengenai bentuk kaki yang misformed misalnya, dia mengatakan jika bentuk kaki yang digambarkan besar tersebut merupakan gambaran kaki-kaki rakyat pekerja keras yang merujuk pada status kasta proletar.

Dalam lukisan berjudul 'Pasar' Hendra Gunawan menggambarkan suasana transaksi jual beli yang terjadi disebuah pasar antara 2 orang perempuan, terlihat dibagian belakang 2 sosok lain dengan latar belakang jalanan tanah dan beberapa bagian digambarkan gelap. Lukisan ini dipersepsi sebagai penggambaran sosok perempuan mandiri yang dibingkai dengan menguasai bidang lukisan. Dalam prespektif ideologi sosialisme penindasan terhadap kaum perempuan dimulai dengan adanya kepemilikan personal yang terlahir ketika sosok laki -laki ditempatkan sebagai figur pencari nafkah sehingga melahirkan pemahaman bahwa anak dan istri yang dinafkahi adalah bagian dari kepemilikan personal, sehingga menciptakan kelas antar gender yang menempatkan laki-laki lebih tinggi dari perempuan.

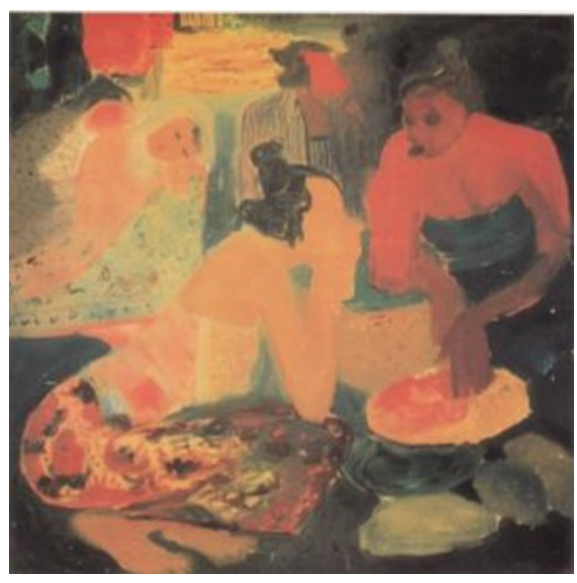

Gambar 3. Lukisan Hendra Gunawan, Pasar (1960) Sumber:http://archive.ivaa-online.org/pelakuseni/ hendra-gunawan/page:2

Kemunculan ide-ide tentang rakyat jelata dan kemandirian perempuan acap kali muncul dalam karya Hendra Gunawan. Selain 2 lukisan tersebut terdapat setidaknya 7 lukisan Hendra Gunawan yang menggambarkan suasana pasar, dimana 3 diantaranya berjudul Pasar, 2 lukisan dipublikasikan tahun 1960, dan 1 lukisan pada tahun 1957.

Menurut hasil wawancara dengan budayawan Al-Hakim, perlu digarisbawahi jika maksud Hendra menggambarkan suasana pasar bukan hanya sekedar menangkap realitas yang ada, tapi memiliki maksud lain. Sebab dari seluruh lukisan bertema pasar yang dibuat oleh Hendra, seluruhnya menggambarkan sosok rakyat kecil sebagai tokoh utama lukisannya. Ini dapat dilihat dari pakaian yang digunakan tokoh-tokoh dalam lukisannya.

Berdasarkan tahapan analisa yang telah dipaparkan di atas, didapatkan hasil dari penghitungan kemunculan tanda yang dihitung untuk mengukur sejauh mana lukisan Hendra Gunawan merepresentasikan kepentingan politik dan ideologi komunisme. Hasil dari penghitungan disajikan dalam tabel sebagai berikut:

Tabel 3. Hasil penghitungan matrix coding

\begin{tabular}{|c|c|c|}
\hline \multicolumn{2}{|c|}{ Indikator } & Persentase \\
\hline \multirow{3}{*}{$\begin{array}{c}\text { Ajaran } \\
\text { Ideologi }\end{array}$} & Komunisme-Sosialisme & $70 \%$ \\
\cline { 2 - 3 } & Kapitalisme & $0 \%$ \\
\hline \multirow{2}{*}{$\begin{array}{c}\text { Kelas } \\
\text { Sosial }\end{array}$} & Bukan keduanya & $30 \%$ \\
\cline { 2 - 3 } & Proletar & $80 \%$ \\
\hline \multirow{2}{*}{$\begin{array}{c}\text { Nilai } \\
\text { Budaya }\end{array}$} & Borjuis & $20 \%$ \\
\cline { 2 - 3 } & Konservatif konservatif kontra-Revolusi & $90 \%$ \\
\cline { 2 - 3 } & Bukan keduanya & $10 \%$ \\
\hline \multirow{2}{*}{$\begin{array}{c}\text { Kondisi } \\
\text { Objek }\end{array}$} & Penciptaan Kondisi Ideal & $10 \%$ \\
\cline { 2 - 3 } & Sesuai Realitas & $90 \%$ \\
\hline \multirow{2}{*}{$\begin{array}{c}\text { Pengala } \\
\text { man } \\
\text { Seniman }\end{array}$} & Berdasar pengalaman & $90 \%$ \\
\cline { 2 - 3 } & Tidak berdasar pengalaman & $10 \%$ \\
\hline
\end{tabular}


Berdasarkan hasil penghitungan diatas, dapat dilihat bahwa terdapat frekuensi yang cukup signifikan yang menunjukan kesesuaian antara tendensi kepentingan politik kelompok komunis dengan hasil interpretasi lukisan berupa pesan yang diungkapkan Hendra dalam lukisan. Sejumlah 4 dari 5 indikator yang menunjukan persentasi yang cukup tinggi $(>70 \%)$ ditandai dengan kemunculan frekuensi hingga $90 \%$.

Indikasi tersebut nampak dari tanda-tanda visual berupa pemunculan sosok perempuan mandiri, penggambaran rakyat jelata, penggunaan warna yang mencolok dan kontras, dan ide tentang semangat bekerja keras bagi semua. Hal tersebut sejalan dengan teks Prinsip Kesenian 1959. Meski dalam karya Hendra Gunawan tidak ditemui lambanglambang eksplisit komunisme. Namun tema-tema kelas sosial, budaya revolusi, dan penceritaan pengalaman sangat dominan dalam karya Hendra Gunawan. Ideologi Komunisme dikemas sedemikian rupa agar tersamar melalui bahasa visual yang halus.

\section{DISKUSI}

Melalui hasil penghitungan pada pembahasan sebelumnya dapat dilihat bahwa lukisan Hendra Gunawan merepresentasikan kepentingan faham ideologi Komunisme, sebab terdapat kesesuaian dalam jumlah signifikan antara lukisan Hendra Gunawan dengan kepentingan politik kelompok komunis yang tertuang dalam Prinsip Kesenian 1959.

\section{Representasi Ideologi Komunis dalam Lukisan Hen- dra Gunawan}

Dalam memandang hasil yang ditunjukan sebagai hasil penghitungan diatas, dari satu sisi dapat dilihat bahwa lukisan Hendra Gunawan adalah representasi kepentingan politik kelompok komunis di ranah kesenian, atau kepentingankepentingan kelompok komunis terepresentasi dengan atau tanpa disengaja. Untuk melihat sejauh mana kemungkinan intervensi yang dilakukan kelompok komunis dalam proses pengkaryaan, idealnya harus dilakukan penelitian lanjutan yang melihat latar belakang pengkaryaan dengan memperhatikan latar peristiwa yang terjadi. Namun terdapat satu poin dalam penelitian ini yang dapat digunakan sebagai acuan dalam menjawab pertanyaan tersebut.

Dapat dilihat dalam proses penghitungan matrix coding diatas bahwa lukisan Hendra Gunawan memenuhi 4 dari 5 aspek yang menunjukan kecenderungan mewakili kepentingan kelompok komunis. Gagasan pengajaran ideologi komunis direpresentasikan melalui penampilan visual kemandirian dan warna-warna kontras yang mendobrak pakem warna 'seniman kebanyakan' yang menggunakan warna-warna unsur bumi dan kalem. Dimana seniman yang dipandang "pro penguasa' acap kali berkarya dengan warna yang tidak mencolok dan kontras. Pada aspek kelas sosial, Hendra Gunawan nampak vokal menyuarakan ide-ide tentang kehidupan kaum bawah, teramat jarang menampakkan visual kaum berada. Hal ini bisa dianggap sebagai usaha memarjinalkan 'petinggi negeri' pada kala itu. Sejalan dengan kepentingan politik partai komunis kala itu yang memulai revolusi dengan menggerakkan masyarakat arus bawah. Pada aspek nilai-nilai budaya revolusi, ide-ide yang sejalan dengan kepentingan partai komunis masih juga menguasai lukisan-lukisan karya Hendra Gunawan. Ditandai dengan tema-temanya yang tidak lazim, menggugah semangat untuk menggerakkan potensi masyarakat bawah.

Namun menariknya, dalam poin ke-4 berupa kondisi objek yang digambarkan melalui sudut pandang realitas, Hendra Gunawan tampak mengabaikan penggambaran kondisi ideal revolusi seperti tuntutan kelompok komunis dalam Prinsip Kesenian 1959. Hal ini dapat berarti bahwa idealisme Hendra sebagai seorang pelukis masih terjaga, dan karya yang dihasilkannya berasal dari gagasannya sendiri. Meskipun pada akhirnya gagasan tersebut kemudian merepresentasikan kepentingan politik kelompok komunis. Mengenai pandangan tersebut menurut Nugraha [10] merupakan bagian dari interpretasi yang dapat meluas melebihi makna atau pesan yang dimaksud oleh pencipta karya, yang dalam hal ini oleh Hendra Gunawan sendiri. Selain itu menurut Suriasumantri dalam Halimatussadiah [11] jika dikaitkan dengan teori aksiologi dalam pembahasan estetika, bahwa sebagai bagian dari ilmu pengetahuan sebuah karya terlepas dari faktor-faktor eksternal dan bebas nilai, maka penilaian bahwa sebuah karya yang dianggap merepresentasikan suatu hal adalah penilaian subjektif dari subjek yang menilai. Sementarai nilai sebenarnya haruslah berasal dari objek. Maka dapat dikatakan jika pengelompokan karya Hendra Gunawan atau karya-karya lain sebagai representasi kelompok tertentu menghasilkan kemungkinan bahwa penilaian tersebut bersifat subjektif, dengan alasan yang beragam. 


\section{KESIMPULAN}

Setelah dilakukan penelitian terhadap sampel yang didapatkan dengan metode yang telah dijelaskan sebelumnya didapatkan kesimpulan antara lain bahwa lukisan Hendra mengandung banyak pesan yang selaras dengan ajaran-ajaran dari faham komunisme-sosialisme, dan cukup ideal bagi kepentingan politik yang tengah dijalankan PKI yang dibuktikan dengan memenuhi 4 dari 5 indikator penelitian yang ditetapkan. Namun idealisme Hendra dalam berkarya yang ditunjukan dengan pembuatan karya sesuai kehendaknya sendiri, bercerita jujur berdasarkan pengalamannya sendiri, menunjukan bahwa tidak terdapat intervensi dalam proses pembuatan karyanya. Atau bisa diartikan juga bahwa intervensi politik yang ada kala itu tidak mempengaruhi Hendra Gunawan dalam menghasilkan lukisan. Sebab jika intervensi partai memang ada sekalipun, Hendra tetap menunjukan sikap yang jelas dalam menghasilkan karya, tanpa pengaruh siapapun.

Adapun Mengenai lukisannya yang dapat dikatakan sebagai lukisan ideal bagi PKI, yang kemudian memunculkan tuduhan tentang intervensi partai terhadapnya, dapat difahami sebagai sikap Hendra yang mungkin memang sudah sejalan sejak awal. Mengigat ia merupakan salah satu tokoh Lekra. Untuk menyimpulkan bahwa sikap tersebut muncul karena intervensi, perlu kajian lebih lanjut dan lebih komprehensif tentang sosok Hendra terlepas dari lukisan-lukisannya.

\section{SARAN}

Faktor intervensi yang tidak dapat dinilai dalam penelitian ini menyisakan satu pertanyaan tentang posisi Hendra ditengah situasi politik 1950-1965 yang idealnya dapat terjawab dalam penelitian selanjutnya. Selain itu, penelitian yang berfokus pada 1 objek juga menyisakan ruang yang masih luas untuk diteliti dalam upaya rekonstruksi peristiwa pada masa tersebut, yang semoga dapat diselesaikan dalam penelitian selanjutnya.

\section{UCAPAN TERIMA KASIH}

Penulis mengucapkan terima kasih kepada semua pihak yang telah berperan memberikan sumbangan waktu, tenaga dan buah pikirannya selama proses penulisan naskah ini. Semoga segala kebaikan yang penulis terima dari berbagai pihak yang terlibat dibalas oleh Allah SWT dengan limpahan kebaikan. Sehingga pada akhirnya penelitian ini dapat bermanfaat untuk semua orang guna untuk kemajuan dunia seni dan desain Indonesia.

\section{DAFTAR PUSTAKA}

[1] M. Suryajaya, "Estetika Orde Baru." Indoprogress, March 16, 2016. [Online] A v a i l a b I e : h t t p s ; / / indoprogress.com/2016/03/ estetika-ordebaru/

[2] W. Herlambang, "Cultural Violence: its Practice and Chalenge in Indonesia." Disertasi Doktoral. University of Queensland, Australia, 2011.

[3] A. Supartono, Lekra vs Manikebu: Perdebatan Kebudayaan Indonesia 1950 1965. Jakarta: Edy Cahyono Experience, 2005.

[4] T. Djajadi, “Lekra dan Seni Kerakyatan: Kajian karya pelukis Lekra periode 19501965." Jurnal Tingkat Sarjana Bidang Seni Rupa; Institut Teknologi Bandung, 2009.

[5] I. Kurniawan, "The Sensuality And Tendency Of Fetishism On Model Photography." International Conference on Business, Economic, Social Science and Humanities (ICOBEST 2018), p. 339-344, 2018. [Abstract]. Available: Atlantic Press, https:// doi.org/10.2991/icobest-18.2018.75.

[6] I. Kurniawan, \& I.Rocmawati, "Gaya Berkendara dalam Iklan: Antara Representasi Ketangguhan dan Kecerobohan." Mediator. Vol. 11, no. 1, pp. 44-55, 2018. Available: 
https://ejournal.unisba.ac.id/index.php/ mediator/article/view/3154.

[7] B. Firmansyah, Beny "Representasi Nasionalisme Dalam Film (Analisis Isi pada Film 300 Karya Zack Snyder)." Thesis, University of Muhammadiyah Malang, 2011.

[8] B. Mudjiyanto, "Representasi Umat Islam Dalam Tajuk Rencana Surat Kabar Ibukota Mengenai Kasus Makam Mbah Priok Analisis Isi Terhadap Tajuk Rencana Suratkabar Ibukota." Jurnal Studi Komunikasi Dan Media. Vol. 15 No. 1, pp. 19-52, Jan - Jun 2011.

[9] A. Cahyana, A. Pandanwangi, H. Santosa, \& L. Wisyasari, "Tubuh Sebagai Media Ungkap pada Bahasa Rupa Karya Lukis Hendra Gunawan dan Jeihan Sukmantoro." Project Report. Program Studi Seni Rupa Murni UK. Maranatha, Bandung, 2009.
[10] A. F. Nugraha, "Provokasi Visual Dalam Lukisan." Jurnal Invensi, vol. 1, no. 1, pp. 3749, 2016. Available: https://journal.isi.ac.id/ index.php/invensi/article/view/1586.

[11] S. Halimatussadiah, "Ringkasan Filsafat IImu Jujun S. Sumantri" in Academia.edu. A $v$ a i l a b l e : $\quad h$ t $\mathrm{p}: / /$ w w w. academia.edu/8624371/ Ringkasan_Filsafat_Ilmu_Jujun_S._Sumantri 